\title{
HUBUNGAN ANTARA PENGAMBILAN KEPUTUSAN DAN MANAJEMEN STRATEGI
}

\author{
Oleh: Aisiyah Rahmayanti \& Septia Wahyu Monica
}

\begin{abstract}
Pada situasi ini sangat penting juga adanya manajemen strategi karena bersinambungan dengan masalah jika masalah atau situasin baik berarti manajemen strategiknya baik dan bertanggang jawab jika manajemennya tidak baik akan mendapatkan keputusan atau situasi yang buruk. Menurut James A.F.Stoner, Pengambilan keputusan adalah proses yang digunakan untuk memilih suatu tindakan sebagai cara pemecahan masalah. Pengambilan keputusan perlu untuk bisa memilih dan mempertanggung jawabkan pilihan yang sudah ditentukan serta mengetahui resiko apapun keputusan yang diambil untuk keputusan tersebut. Dalam mengambil keputusan melakukan dengan bersama dalam situasi apapun seperti keputusan dalam perusahaan, organisasi dan lainnya. Menurut Robinson (1997) : Manajemen strategi adalah seperangkat strategi dan tindakan yang menyebabkan perumusan (formulasi) dan pelaksanaan (implementasi) rencana yang dirancang untuk mencapai tujuan organisasi. Manajemen strategi berperan dalam situasi pengambilan keputusan karena masalah bisa terjadi dan juga memiliki peran yang bersama dengan pengambilan keputusan dalam hal ini baik dilakukan dengan bersama.
\end{abstract}

Keyword : Pengambilan Keputusan, Manajemen strategik 


\section{BAB 1 \\ PENDAHULUAN}

\section{LATAR BELAKANG}

Pada era globalisasi ini cukup mengemparkan kerena masalah yang telah beredar menjadi semuanya salah paham serta merusak kepercayaan, oleh kerena itu masalah harus bisa didiskusikan bersama dan memutuskan bersama karena bisa saling bertukar pikiran bersama dan menerima masalah serta keputusan bersama. Pada situasi ini sangat penting juga adanya manajemen strategi karena bersinambungan dengan masalah jika masalah atau situasin baik berarti manajemen strategiknya baik dan bertanggang jawab jika manajemennya tidak baik akan mendapatkan keputusan atau situasi yang buruk.

Menurut S.P.Siagian, Pengambilan Keputusan adalah suatu pendekatan yang sistematis terhadap hakikat alternative yang dihadapi dan mengambil tindakan yang menurut perhitungan merupakan tindakan yang paling tepat. Menurut James A.F.Stoner, Pengambilan keputusan adalah proses yang digunakan untuk memilih suatu tindakan sebagai cara pemecahan masalah. Pengambilan keputusan perlu untuk bisa memilih dan mempertanggung jawabkan pilihan yang sudah ditentukan serta mengetahui resiko apapun keputusan yang diambil untuk keputusan tersebut. Dalam mengambil keputusan melakukan dengan bersama dalam situasi apapun seperti keputusan dalam perusahaan, organisasi dan lainnya.

Menurut Alex Miller (2003) : Manajemen strategi adalah suatu proses kombinasi antara tiga aktivitas yaitu analisis strategi, perumusan strategi dan implentasi strategi. Menurut Robinson (1997) : Manajemen strategi adalah seperangkat strategi dan tindakan yang menyebabkan perumusan (formulasi) dan pelaksanaan (implementasi) rencana yang dirancang untuk mencapai tujuan organisasi. Manajemen strategi berperan dalam situasi pengambilan keputusan karena masalah bisa terjadi dan juga memiliki peran yang bersama dengan pengambilan keputusan dalam hal ini baik dilakukan dengan bersama.

\section{POKOK PERMASALAHAN}

1. Apakah pengambilan keputusan berdampak baik jika memiliki manajemen strategi 
2. Apakah manajemen strategi bisa melakukan pengambilan keputusan yang baik dan benar

3. Apa dampak dari manajemen strategik dan pengambilan keputusan

\section{BAB 2}

\section{KERANGKA TEORI}

\subsection{PENGAMBILAN KEPUTUSAN}

\subsubsection{PENGERTIAN}

Menurut S.P.Siagian, Pengambilan Keputusan adalah suatu pendekatan yang sistematis terhadap hakikat alternative yang dihadapi dan mengambil tindakan yang menurut perhitungan merupakan tindakan yang paling tepat. Menurut James A.F.Stoner, Pengambilan keputusan adalah proses yang digunakan untuk memilih suatu tindakan sebagai cara pemecahan masalah. Menurut Fred R. David : Manajemen strategi adalah seni dan ilmu merumuskan, melaksanakan, dan mengevaluasi keputusan lintas fungsional yang memungkinkan organisasi untuk mencapai tujuan.

\subsubsection{MANFAAT}

Manfaat pengambilan keputusan untuk mempercepat penyelesaiaan masalah dan untuk memperkirakan masalah-masalah baru yang akan mungkin akan timbul sehubungan dengan alternatif yang dipilih.

\subsubsection{TUJUAN}

Tujuan pengambilan keputusan adalah untuk menyelesaikan masalah atau setidaktidaknya dapat mempersempit /memperkecil masalah, Didalam rangkah pengambilan keputusan, maka pertama-tama yang harus ditentukan adalah penentuan tujuan, baik tujuan yang bersifat keharusan maupun tujuan yang bersifat keinginan. Tujuan keharusan merupakan tujuan mutlak yang harus dipenuhi oleh setiap alternatif yang ada tanpa kecuali. Karena itu tujuan keharusan bisa digunakan untuk sortasi awal terhadap alternatif-alternatif yang ada. Tujuan keharusan biasanya bisa diukur secara tepat. Sedangkan tujuan keinginan 
merupakan sejumlah tujuan yang dikehendaki oleh si pembuat keputusan yang berguna untuk menentukan manakah dari alternatif-alternatif yang telah tersortir diatas akan terpilih.

\subsubsection{PROSES PENGAMBILAN KEPUTUSAN}

Dari pendapat pendapat yang telah dikemukaakan diatas dapat disimpulkan bahwa proses pengambilan keputusan itu meliputi:

\section{IDENTIFIKASI MASALAH}

Seseorang mula-mula harus menyadari dan menepatkan diri sebagai pimpinan dalam suatu organisasi yang harus bertanggung jawab sebagai pimpinan organisasi. Sebagai pimpinan harus memutuskan sesuatu jika dalam organisainya itu terdapat masalah 2. KALSIFIKASI MASALAH

Masalah yang dihadapi lebih dahulu harus dianalisa, mengingat bahwa masalah itu mempunyai bermacam-macam sifat, bentuk dan kopleksitasnya.

3. Mencari dan mengembangkan alterantif, juga harus dianalisa dan dikembangkan situasi yang mempengaruhi baik organisasinya maupn itu masalahnya.

\section{ANALISA ALTERNATIF}

Kemudian perlu menganalisa keputusan itu sendiri yang harus dinuatnya, terutama yang adianalisa adalah alternatif-alternatif yang dikemukakan dengan konsekwensi masingmasing. Untuk kemudian dipilih satu diantara alternatif tersebut yang dianggap paling tepat.

\section{PENGAMBILAM KEPUTUS}

Setelah keputusan diambil maka keputusan itu kemudian dialaksanakan. Keberhasilan pelaksanaan keputusan itu akan saling terpengaruh dari jiwa kepemimpinan dan managemen dari pimpinan yang bersangkutan .

6. Memantau dan mengevaluasi hasil pelaksanaan keputusan, setiap langkah pelaksanaan keputusan harus diikuti dengan evaluasi. Sdetiap langkah diadakan pemantuan, hasilnya segera dievaluasi untuk menentukan apakah pelaksanaan itu masih sesuai dengan yang diharapkan. 


\subsection{MANAJEMEN STRATEGI}

\subsubsection{PROSES DAN TAHAPAN MANAJEMEN STRATEGI}

David (2011:6)menjelaskan bahwa proses manajemen strategis terdiri dari tiga tahapan, yaitu :

\section{a. Perumusan Strategi (Strategy Formulation)}

Perumusan strategi adalah tahap awal pada manajemen strategi, yang mencakup mengembangkan visi dan misi, mengidentifikasi peluang eksternal organisasi dan ancaman, menentukan kekuatan dan kelemahan internal, menetapkan tujuan jangka panjang, menghasilkan strategi alternatif, dan memilih strategi tertentu untuk mencapai tujuan.

\section{b. Implementasi Strategi (Strategy Implemented)}

Implementasi strategi adalah tahap selanjutnya sesudah perumusan strategi yang ditetapkan. Penerapan strategi ini memerlukan suatu keputusan dari pihak yang berwenang dalam mengambil keputusan untuk menetapkan tujuan tahunan, menyusun kebijakan, memotivasi karyawan, dan mengalokasikan sumber daya sehingga strategi yang dirumuskan dapat dilaksanakan. Pada tahap ini dilakukan pengembangan strategi pendukung budaya, merencanakan struktur organisasi yang efektif, mengatur ulang usaha pemasaran yang dilakukan, mempersiapkan budget, mengembangkan dan utilisasi sistem informasi serta menghubungkan kompensasi karyawan terhadap kinerja organisasi.

c. Evaluasi Strategi (Strategy Evaluation)

Evaluasi strategi adalah tahap akhir dalam manajemen strategis. Manajer sangat membutuhkan untuk tahu kapan strategi tertentu tidak bekerja dengan baik; Evaluasi strategi adalah alat utama untuk memperoleh informasi ini. Hal tersebut dapat dilakukan dengan penilaian atau melakukan proses evaluasi strategi. Dalam penilaian strategi terdapat tiga aktivitas penilaian yang mendasar, yaitu: Peninjauan ulang faktor-faktor eksternal dan internal yang menjadi landasan bagi strategi saat ini, Pengukuran kinerja, dan 3). Pengambilan langkah korektif. Penilaian strategi sangat diperlukan oleh suatu perusahaan karena strategi yang berhasil untuk saat ini tidak selalu berhasil untuk di masa yang akan datang.

\subsubsection{PENGERTIAN}


Menurut Alex Miller (2003) : Manajemen strategi adalah suatu proses kombinasi antara tiga aktivitas yaitu analisis strategi, perumusan strategi dan implentasi strategi. Menurut Robinson (1997) : Manajemen strategi adalah seperangkat strategi dan tindakan yang menyebabkan perumusan (formulasi) dan pelaksanaan (implementasi) rencana yang dirancang untuk mencapai tujuan organisasi. Menurut Bambang Haryadi (2003:3), strategi manajemen adalah suatu proses yang dirancang secara sistematis oleh manajemen untuk merumuskan strategi, menjalankan strategi dan mengevaluasi strategi dalam rangka menyediakan nilai-nilai yang terbaik bagi seluruh pelanggan untuk mewujudkan visi organisasi.

\subsubsection{TUJUAN MANAJEMEN STRATEGI}

Menurut Suwandiyanto (2010:02), terdapat empat tujuan manajemen strategi, yaitu:

1. Memberikan arah pencapaian tujuan organisasi/perusahaan. Dalam hal ini, manajer strategi harus mampu menunjukkan kepada semua pihak kemana arah tujuan organisasi/perusahaan. Karena, arah yang jelas akan dapat dijadikan landasan untuk pengendalian dan mengevaluasi keberhasilan.

2. Membantu memikirkan kepentingan berbagai pihak. Organisasi/perusahaan harus mempertemukan kebutuhan berbagai pihak, pemasok, karyawan, pemegang saham, pihak perbankan, dan masyarakat luas lainnya yang memegang peranan terhadap sukses atau gagalnya perusahaan.

3. Mengantisipasi setiap perubahan kembali secara merata. Manajemen strategi memungkinkan eksekutif puncak untuk mengantisipasi perubahan dan menyiapkan pedoman dan pengendalian, sehingga dapat memperluas kerangka waktu/berpikir mereka secara perspektif dan memahami kontribusi yang baik untuk hari ini dan hari esok.

4. Berhubungan dengan efisiensi dan efektivitas. Tanggung jawab seorang manajer bukan hanya mengkonsentrasikan terhadap kemampuan atas kepentingan efisiensi, akan tetapi hendaknya juga mempunyai perhatian yang serius agar bekerja keras melakukan sesuatu secara lebih baik dan efektif. 


\subsubsection{ANALISIS SWOT}

Secara umum, analisis swot pada tiap media massa dapat dilakukan, seperti yang diterangkan dibawah ini:

a. Strengths ( kekuatan / kelebihan)

- tersedianya dan untuk memenuhi kebutuhan masyarakat.

- tersedianya undang-undang pers.

- tersedianya fasilitas sarana dan prasarana media massa.

- adanya promosi yang dapat dilakukan.

b. Weaknesses (kelemahan/kekurangan)

- pelayanan terhadap masyarakat.

- mutu/ kualitas sebagian sumber daya manusia (sdm).

- belum optimalnya fungsi pers.

- kurangnya kepedulian pihak swasta terhadap pers.

c. Opportunities (peluang /kesempatan)

- adanya partisipasi dan dukungan masyarakat.

- adanya dukungan pemerintah.

- adanya dunia usaha/industri yang bersedia bekerjasama.

- kebutuhan masyarakat terhadap informasi.

d. Threats ( ancaman)

- perilaku dan budaya masyarakat yang kurang mendukung kerja media.

- masih adanya krisis ekonomi yang melemahkan kemampuan masyarakat secara finanasial.

- belum mempunyai dukungan dari pemerintahan yang otoriter

- image sebagian masyarakat bahwa media tidak menjanjikan masa depan yang lebih baik.

\subsubsection{KRITERIA PENGAMBILAN KEPUTUSAN}

Menurut konsepsi Anderson, nilai-nilai yang kemungkinan menjadi pedoman perilaku para pembuat keputusan itu dapat dikelompokkan menjadi 4 (empat) kategori, yaitu:

1. Nilai-nilai Politik 
Pembuat keputusan mungkin melakukan penilaian atas altematif kebijaksanaan yang dipilihnya dari sudut pentingnya altematif-altematil itu bagi partai politiknya atau bagi kelompok-kelompok klien dari badan atau organisasi yang dipimpinnya. Keputusankeputusan yang lahir dari tangan para pembuat keputusan seperti ini bukan mustahil dibuat demi keuntungan politik' dan kebijaksanaan dengan demikian akan dilihat sebagai instrumen untuk memperluas pengaruh-pengaruh politik atau untuk mencapai tujuan dan kepentingan dari partai politik atau tujuan dari kelompok kepentingan yang bersangkutan. 2. Nilai-nilai organisasi

Para pembuat kepurusan, khususnya birokrat (sipil atau militer), mungkin dalam mengambil keputusan dipengaruhi oleh nilai-nilai organisasi di mana ia terlibat di dalamnya' Organisasi, semisal badan-badan administrasi, menggunakan berbagai bentuk ganjaran dan sanksi dalam usahanya untuk memaksa para anggotanya menerima, dan bertindak sejalan dengan nilai-nilai yang telah digariskan oleh organisasi. Sepanjang nilai-nilai semacam itu ada, orang-orang yang bertindak selaku pengambil keputusan dalam organisasi itu kemungkinan akan dipedomani oleh pertimbangan-pertimbangan semacam itu sebagai perwujudan dari hasrat untuk melihat organisasinya tetap lestari, unuk tetap maju atau untuk memperlancar program-program dan kegiatan-kegiatannya atau atau untuk mempertahankan kekuasaan dan hak-hak istimewa yang selama ini dinikmati.

\section{Nilai-nitai Pribadi}

Hasrat untuk melindungi atau memenuhi kesejateraan atau kebutuhan fisik atau kebutuhan finansial' reputasi diri, atau posisi historis kemungkinan juga digunakan- oleh para pembuat teputusan sebagai kriteria dalam pengambilan keputusan.

Para politisi yang menerima uang sogok untuk membuat kepurusan tertentu yang menguntungkan si pemberi uang sogok, misalnya sebagai hadiah pemberian perizinan atau penandatanganan kontrak pembangunan proyek tertentu, jelas mempunyai kepentingan pribadi dalam benaknya. Seorang presiden yang mengatakan di depan para wartawan bahwa ia akan menggebut siapa saja yang bertindak inkonstirusional, jelas juga dipengaruhi oleh pertimbangan-pertimbangan pribadinya'misalnya agar ia mendapat tempat terhormat dalam sejarah bangsa sebagai seseorang yang konsisten dan nasionalis.

4. Nilai-nilai Kebijaksanaan 
Dari perbincangan di atas, satu hal hendaklah dicamkan, yakni janganlah kita mempunyai anggapan yang sinis dan kemudian menarik kesimpulan bahwa para pengambil keputusan politik inr semata-mata hanyalah dipengaruhi oleh pertimbangan-penimbangan demi keuntungan politik, organisasi atau pribadi. Sebab, para pembuat keputusan mungkin pula bertindak berdasarkan atas penepsi mereka terhadap kepentingan umum atau keyakinan tertentu mengenai kebijaksanaan negara apa yang sekiranya secara moral tepat dan benar. Seorang wakil rakyat yang mempejuangkan undang-undang hak kebebasan sipil mungkin akan bertindak sejalan dengan itu karena ia yakin bahwa tindakan itulah yang secara moral benar, dan bahwa persamaan hak-hak sipil itu memang merupakan tujuan kebijaksanaan negara yang diinginkan, tanpa mempedulikan bahwa perjuangan itu mungkin akan menyebabkannya mengalami resiko-resiko politik yang fatal.

5. Nilai-nilai Ideologis

Ideologi pada hakikatnya merupakan serangkaian nilai-nilai dan keyakinan yang secara logis saling berkaitan yang mencerminkan gambaran sederhana mengenai dunia serta berfungsi sebagai pedoman benindak bagi masyarakat yang meyakininya. Di berbagai negara sedang berkembang di kawasan Asia, Afrika dan Timur Tengah nasionalisme yang mencerminkan hasrat dari orang-orang atau bangsa yang bersangkutan untuk merdeka dan menentukan nasibnya sendiri — telah memberikan peran penting dalam mewamai kebijaksanaan luar negeri maupun dalam negeri mereka. Pada masa gerakan nasional menuju kemerdekaan, nasionalisme telah berfungsi sebagai minyak bakar yang mengobarkan semangat perjuangan bangsa-bangsa di negara-negara sedang berkembang melawan kekuatan kolonial. 


\section{BAB 3}

\section{METODE PENELITIAN}

\section{Pengertian Manajemen Strategi}

Manajemen Strategi merupakan rangkaian dua perkataan terdiri dari kata "Manajemen" dan "Strategi" yang masing-masing memiliki pengertian tersendiri, yang setelah dirangkaikan menjadi satu terminologi berubah dengan memiliki pengertian tersendiri pula. Menurut Hadari Nawawi (2005:148-149), pengertian manajemen strategi ada 4 (empat). Pengertian pertama Manajemen Strategi adalah "proses atau rangkaian

kegiatan pengambilan keputusan yang bersifat mendasar dan menyeluruh, disertai penetapan cara elaksanakannya, yang dibuat oleh manajemen puncak dan dimplementasikan oleh seluruh jajaran di dalam suatu organiasasi, untuk mencapai tujuannya”. Dari pengertian tersebut terdapat beberapa aspek yang penting, antara lain :

(a) Manajemen Strategi merupakan proses pengambilan keputusan.

(b) Keputusan yang ditetapkan bersifat mendasar dan menyeluruh yang berarti berkenaan dengan aspek - aspek yang penting dalam kehidupan sebuah organisasi, terutama tujuannya dan cara melaksanakan atau cara mencapainya.

(c) Pembuatan keputusan tersebut harus dilakukan atau sekurang-kurangnya melibatkan pimpinan puncak (kepala sekolah), sebagai penanggung jawab utama pada keberhasilan atau kegagalan organisasinya.

(d) Pengimplementasian keputusan tersebut sebagai strategi organisasi untuk mencapai tujuan strateginya dilakukan oleh seluruh jajaran organisasi (warga sekolah), seluruhnya harus mengetahui dan menjalankan peranan sesuai wewenang dan tanggung jawab masing - masing.

(e) Keputusan yang ditetapkan manajemen puncak (kepala sekolah) harus diimplementasikan oleh seluruh warga sekolah dalam bentuk kegiatan/pelaksanaan pekerjaan yang terarah pada tujuan strategi organisasi. 
(f) Pengertian manajemen strategi yang kedua adalah "usaha manajerial menumbuhkembangkan kekuatan organisasi untuk mengeksploitasi peluang yang muncul guna mencapai tujuannya yang telah ditetapkan sesuai dengan misi yang telah ditentukan”. Dari pengertian tersebut terdapat konsep yang secara relatif luas dari

Pengertian pertama yang menekankan bahwa "manajemen strategi merupakan usaha manajerial menumbuhkembangkan kekuatan organisasi”, yang mengharuskan kepala sekolah dengan atau tanpa bantuan manajer bawahannya (Wakasek, Pembina Osis, Kepala Tata Usaha), untuk mengenali aspek - aspek kekuatan organisasi yang sesuai dengan misinya yang harus ditumbuhkembangkan guna mencapai tujuan strategi yang telah ditetapkan.

Pengertian yang kedua, Untuk setiap peluang atau kesempatan yang terbuka harus dimanfaatkan secara optimal.

Pengertian yang ketiga, Manajemen Strategi adalah "arus keputusan dan tindakan yang mengarah pada pengembangan strategi yang efektif untuk membantu mencapai tujuan organisasi”. Pengertian ini menekankan bahwa arus keputusan dari para pimpinan organisasi (Ka Dinas, Kepala Sekolah) dan tindakan berupa pelaksanaan keputusan, harus menghasilkan satu atau lebih strategis, sehingga dapat memilih yang paling efektif atau yang paling handal dalam usaha mencapai tujuan organisasi.

Pengertian yang keempat, "manajemen strategi adalah perencanaan berskala besar (disebut Perencanaan Strategi) yang berorientasi pada jangkauan masa depan yang jauh (disebut VISI), dan ditetapkan sebagai keputusan manajemen puncak (keputusan yang bersifat mendasar dan prinsipil), agar memungkinkan organisasi berinteraksi secara efektif (disebut MISI), dalam usaha menghasilkan sesuatu (Perencanaan Operasional) yang berkualitas, dengan diarahkan pada optimalisasi pencapaian tujuan (disebut Tujuan Strategi) dan berbagai sasaran (Tujuan Operasional) organisasi.”

Pengertian yang kelima cukup luas ini menunjukkan bahwa Manajemen Strategi merupakan suatu sistem yang sebagai satu kesatuan memiliki berbagai komponen yang 
saling berhubungan dan saling mempengaruhi, dan bergerak secara serentak ke arah yang sama pula. Komponen pertama adalah Perencanaan Strategi dengan unsur - unsurnya yang terdiri dari Visi, Misi, Tujuan Strategi organisasi. Sedang komponen kedua adalah Perencanaan Operasional dengan unsur - unsurnya adalah Sasaran atau Tujuan Operasional, Pelaksanaan Fungsi-fungsi manajemen berupa fungsi pengorganisasian, fungsi pelaksanaan dan fungsi penganggaran, kebijaksanaan situasional, jaringan kerja Internal dan eksternal, fungsi kontrol dan evaluasi serta umpan balik.

Di samping itu dari pengertian Manajemen Strategi yang terakhir, dapat disimpulkan beberapa karakteristiknya sebagai berikut :

a) Manajemen Strategi diwujudkan dalam bentuk perencanaan berskala besar dalam arti mencakup seluruh komponen di lingkungan sebuah organisasi yang dituangkan dalam bentuk Rencana Strategi (RENSTRA) yang dijabarkan menjadi Perencanaan Operasional (RENOP), yang kemudian dijabarkan pula dalam bentuk Program - program kerj

b) Rencana Strategi berorientasi pada jangkauan masa depan ( 25 - 30 tahun). Sedang Rencana Operasionalnya ditetapkan untuk setiap tahun atau setiap lima tahun.

c) VISI, MISI, pemilihan strategi yang menghasilkan Strategi Utama (Induk) dan Tujuan Strategi Organisasi untuk jangka panjang, merupakan acuan dalam merumuskan RENSTRA, namun dalam teknik penempatannya sebagai keputusan Manajemen Puncak secara tertulis semua acuan tersebut terdapat di dalamnya.

d) RENSTRA dijabarkan menjadi RENOP yang antara lain berisi program program operasional.

e) Penetapan RENSTRA dan RENOP harus melibatkan Manajemen Puncak (Pimpinan) karena sifatnya sangat mendasar dalam pelaksanaan seluruh misi organisasi.

f) Pengimplementasian Strategi dalam program - program untuk mencapai sasarannya masing - masing dilakukan melalui fungsi - fungsi manajemen yang mencakup pengorganisasian, pelaksanaan, penganggaran dan kontrol. 
Berdasarkan karakteristik dan komponen Manajemen Strategi sebagai sistem, terlihat banyak faktor yang mempengaruhi tingkat intensitas dan formalitas pengimplementasiannya di lingkungan organisasi non profit (pendidikan). Beberapa faktor tersebut antara lain adalah ukuran besarnya organisasi, gaya manajemen dari pimpinan, kompleksitas lingkungan ideologi, sosial politik, sosial ekonomi, sosial budaya termasuk kependudukan, peraturan pemerintah dsb. sebagai tantangan eksternal. Tingkat intensitas dan formalitas itu dipengaruhi juga oleh tantangan internal, antara lain berupa kemampuan menterjemahkan strategi menjadi proses atau rangkaian kegiatan pelaksanaan pekerjaan sebagai pelayanan umum yang efektif, efisien dan berkualitas (dalam bidang pendidikan misalnya menetapkan model/sistem instruksional, sumber sumber belajar, media pembelajaran dll).

\section{Dimensi - Dimensi Manajemen Strategi}

\[ \begin{array}{c}\text { Berdasarkan } \\ \text { pengertian dan karakteristiknya dapat disimpulkan }\end{array} \]
bahwa Manajemen
Strategi memiliki beberapa dimensi atau bersifat
multidimensional. Dimensi - dimensi dimaksud adalah:

a) Dimensi Waktu dan Orientasi Masa Depan

Manajemen Strategi dalam mempertahankan dan mengembangkan eksistensi suatu organisasi berpandangan jauh ke masa depan, dan berperilaku proaktif dan antisipatif terhadap kondisi masa depan yang diprediksi akan dihadapi. Antisipasi masa depan tersebut dirumuskan dan ditetapkan sebagai Visi organisasi yang akan diwujudkan 25 - 30 tahun lebih di masa depan. Menurut Hadari Nawawi (2005 : 155), Visi dapat diartikan sebagai "kondisi ideal yang ingin dicapai dalam eksistensi organisasi di masa depan”. Sehubungan dengan itu Lonnie Helgerson yang dikutip oleh J. Salusu dalam bukunnya Hadari Nawawi mengatakan bahwa : "Visi adalah gambaran kondisi masa depan dari suatu organisasi yang belum tampak sekarang tetapi merupakan konsepsi yang dapat dibaca oleh setiaporang (anggota organisasi). Visi memiliki kekuatan yang mampu mengundang, memanggil, dan menyerukan pada setiap orang untuk memasuki masa depan. Visi organisasi harus dirumuskan oleh manajemen puncak 
organisasi". Masih menurut J. Salusu yang mengutip pendapat Naisibit : "Visi merupakan gambaran yang jelas tentang apa yang akan dicapai berikut rincian dan instruksi setiap langkah untuk mencapai tujuan. Suatu visi dikatakan efektif jika sangat diperlukan dan memberikan kepuasan, menghargai masa lalu sebagai pengantar massa depan”. Masih dalam Hadari Nawawi, menurut Kotler yang juga dikutip oleh J. Salusu dikatakan bahwa : "Visi adalah pernyataan tentang tujuan organisasi yang diekspresikan dalam produk dan pelayanan yang ditawarkan, kebutuhan yang dapat ditanggulangi, kelompok masyarakat yang dilayani, nilai-nilai yang diperoleh, serta aspirasi dan cita - cita masa depan. Sehingga secara sederhana Visi organisasi dapat diartikan sebagai sudut pandang ke masa depan dalam mewujudkan tujuan strategi organisasi, yang berpengaruh langsung pada misinya sekarang dan di masa depan. Sehubungan dengan itu Misi organisasi pada dasarnya berarti keseluruhan tugas pokok yang dijabarkan dari tujuan strategi untuk mewujudkan visi organisasi.

b) Dimensi Internal dan Eksternal

Dimensi Internal adalah kondisi organisasi non profit (pendidikan) pada saat sekarang, berupa kekuatan, kelemahan, peluang dan hambatan yang harus diketahui secara tepat. Untuk itu perlu dilakukan kegiatan EVALUASI DIRI antara lain dengan menggunakan Analisis Kuantitatif dengan menggunakan perhitungan - perhitungan statistik, menggunakan data kuantitatif yang tersedia di dalam Sistem Informasi Manajemen(SIM). Namun kerap kali data kuantitatif tidak memadai, karena lemahnya SIM dalam mencatat, mencari, melakukan penelitian dan mengembangkan data pada masa lalu. Oleh karena itu Evaluasi Diri tidak boleh tergantung sepenuhnya pada data kuantitatif, karena dapat juga dilakukan dengan Analisis Kualitatif dengan menggunakan berbagai informasi kualitatif atau sebagian data kuantitatif dan sebagian lagi data kualitatif. Untuk Analisis Kualitatif dapat dilakukan dengan menggunakan Analisis SWOT. Dimensi lingkungan eksternal pada dasarnya merupakan analisis terhadap lingkungan sekitar organisasi (sekolah), yang terdiri dari Lingkungan Operasional, Lingkungan Nasional dan Lingkungan Global, yang mencakup berbagai aspek atau kondisi, antara lain kondisi sosial politik, sosial ekonomi, sosial budaya, kemajuan dan perkembangan ilmu dan teknologi, adat istiadat, agama, dll. Pengimplementasian 
Manajemen Strategi perlu mengidentifikasi dan mendayagunakan kelebihan atau kekuatan dan mengatasi hambatan atau kelemahan organisasi.

c) Dimensi Pendayagunaan Sumber - Sumber.

Manajemen strategi sebagai kegiatan manajemen tidak dapat melepaskan diri dari kemampuan mendayagunakan berbagai sumber daya yang dimiliki, agar secara terintegrasi terimplementasikan dalam fungsi - fungsi manajemen ke arah tercapainya sasaran yang telah ditetapkan di dalam setiap RENOP, dalam rangka mencapai Tujuan Strategi melalui pelaksanaan Misi untuk mewujudkan Visi Organisasi (sekolah).

Sumber daya yang ada terdiri dari Sumber Daya Material khususnya berupa sara dan prasarana, Sumber Daya finansial dalam bentuk alokasi dana untuk setiap program, Sumber Daya Manusia, Sumber Daya Teknologi dan Sumber Daya Informasi. Semua sumberdaya ini dikategorikan dalam sumber daya internal, yang dalam rangka evaluasi diri (Analisis Internal) harus diketahui dengan tepat kondisinya.

d) Dimensi Keikutsertaan Manajemen Puncak (Pimpinan)

Manajemen strategi yang dimulai dengan menyusun Rencana Strategi merupakan pengendalian masa depan organisasi, agar eksistensi sesuai dengan visinya dapat diwujudkan. Rencana Strategi harus mampu mengakomodasi seluruh aspek kehidupan organisasi yang berpengaruh pada eksistensinya di masa depan merupakan wewenag dan tanggung jawab manajemen puncak. Rencana Strategi sebagai keputusan utama yang prinsipil, tidak saja ditetapkan dengan mengikutsertakan, tetapi harus dilakukan secara proaktif oleh manajemen puncak, karena seluruh kegiatan untuk merealisasikannya merupakan tanggung jawabnya.

e) Dimensi Multi Bidang

Manajemen Strategi sebagai Sistem, pengimplementasiannya harus didasari dengan menempatkan organisasi sebagai suatu sistem. Dengan demikian berarti sebuah organisasi akan dapat menyusun RENSTRA dan RENOP jika tidak memiliki keterikatan atau ketergantungan sebagai bawahan pada organisasi lain sebagai 
atasan. Dalam kondisi sebagai bawahan (sekolah merupakan bawahan Dinas P \& K) berarti tidak memiliki kewenangan penuh dalam memilih dan menetapkan visi, misi, tujuan dan strategi. Sekolah hanya berperan sebagai penyusun RENOP dan program tahunan. Dari uraian tersebut jelas bahwa RENSTRA dan RENOP bersifat multi dimensi, terutama jika perumusan RENSTRA hanya dilakukan pada banyak organisasi non profit termasuk pendidikan yang tertinggi. Dengan dimensi yang banyak tersebut, maka mudah terjadi tidak seluruh dimensi dapat diakomodasi.

\section{Keunggulan dan Manfaat Manajemen Strategi Bagi Organisasi}

Pendidikan Pengimplementasian Manajemen Strategi melalui perumusan RENSTRA dan RENOP dengan menggunakan strategi tertentu dalam melaksanakan fungsi-fungsi manajemen, dan mewujudkan tugas pokok dilingkungan organisasi pendidikan harus diukur dan dinilai keunggulannya. Dari pengukuran tersebut dan seluruh proses pengimplementasiannya, maka diketahui manfaat Manajemen Strategi bagi organisasi.

Keunggulan dan Manfaat Manajemen Strategi dalam organasasi pendidikan antara lain :

a. Keunggulan Implementasi Manajemen Strategi

Keunggulan implementasi manajemen strategi dapat dievaluasi dengan menggunakan

tolok ukur sebagai berikut :

\section{1) Profitabilitas}

Keunggulan ini menunjukkan bahwa seluruh pekerjaan diselenggarakan secara efektif dan efisien, dengan penggunaan anggaran yang hemat dan tepat, sehingga diperoleh profit berupa tidak terjadi pemborosan.

\section{2) Produktivitas Tinggi}

Keunggulan ini menunjukkan bahwa jumlah pekerjaan (kuantitatif) yang dapat diselesaikan cenderung meningkat. Kekeliruan atau kesalahan dalam bekerja semakin berkurang dan kualitas hasilnya semakin tinggi, serta yang 
terpenting proses dan hasil memberikan pelayanan umum (siswa dan masyarakat) mampu memuaskan mereka.

\section{3) Posisi Kompetitif}

Keunggulan ini terlihat pada eksistensi sekolah yang diterima, dihargai dan dibutuhkan masyarakat. Sifat kompetitif ini terletak pada produknya (mis : kualitas lulusan) yang memuaskan masyarakat yang dilayani.

\section{4) Keunggulan Teknologi}

Semua tugas pokok berlangsung dengan lancar dalam arti pelayanan umum dilaksanakan secara cepat, tepat waktu, sesuai kualitas berdasarkan tingkat keunikan dan kompleksitas tugas yang harus diselesaikan dengan tingkat rendah, karena mampu mengadaptasi perkembangan dan kemajuan teknologi.

\section{5) Keunggulan SDM}

Di lingkungan organisasi pendidikan dikembangkan budaya organisasi yang menempatkan manusia sebagai faktor sentral, atau sumberdaya penentu keberhasilan organisasi. Oleh karena itu SDM yang dimiliki terus dikembangkan dan ditingkatkan pengetahuan, ketrampilan, keahlian dan sikapnya terhadap pekerjaannya sebagai pemberi pelayanan kepada siswa. Bersamaan dengan itu dikembangkan pula kemampuan memecahkan masalah yang dihadapi oleh sekolah pada masa sekarang dan untuk mengantisipasi masalah -masalah yang timbul sebagai pengaruh globalisasi di masa yang akan datang.

\section{6) Iklim Kerja}

Tolok ukur ini menunjukkan bahwa hubungan kerja formal dan informal dikembangkan sebagai budaya organisasi berdasarkan nilai - nilai kemanusiaan. Di dalam budaya organisasi pendidikan, setiap SDM sebagai individu dan anggota organisasi terwujud hubungan formal dan hubungan informal antar personil yang harmonis sesuai dengan posisi, wewenang dan tanggung jawab masing - masing di dalam dan di luar jam kerja. 


\section{7) Etika dan Tanggung Jawab Sosial}

Tolok ukur ini menunjukkan bahwa dalam bekerja terlaksana dan dikembangkan etika dan tanggung jawab sosial yang tinggi, dengan selalu mendahulukan kepentingan masyarakat, bangsa dan negara di atas kepentingan pribadi, kelompok dan/atau organisasi. Tolok ukur keunggulan tersebut di atas sangat penting artinya bagi kehidupan bermasyarakat, berbangsa dan bernegara sekarang dan di masa mendatang. Untuk itu diperlukan kerjasama dan dukungan masyarakat dalam menumbuhkembangkan organisasi dalam mengimplementasikan Manajemen Strategi secara optimal, agar keunggulan - keunggulan di atas dapat diwujudkan yang hasilnya akan menguntungkan masyarakat pula. Dalam kenyataan yang pada masa sekarang, bagi organisasi pendidikan (sekolah) kondisi untuk mewujudkan keunggulan tersebut masih menghadapi berbagai dilema. Organisasi pendidikan yang ada pada saat ini secara relatif bersifat konsumtif, sedang untuk melaksakan Manajemen Strategi secara relatif diperlukan dana/anggaran yang tidak sedikit. Dalam kondisi seperti ini sangat diperlukan kemampuan mewujudkan keseimbangan antara kesediaan pemerintah dalam menyediakan dana/anggaran yang memadai, dan dalam menggali serta mengatur pendayagunaan sumber - sumber daya lain, seperti orang tua, masyarakat, pinjaman/bantuan.

\section{b. Manfaat Menejemen Strategi}

Berdasarkan keunggulan yang dapat diwujudkan seperti telah diuraikan di atas, berarti dalam pengimplemantasian Manajemen Strategi di lingkungan organisasi pendidikan terdapat beberapa manfaat yang dapat memperkuat usaha mewujudkannya secara efektif dan efisien. Manfaat yang dapat dipetik adalah : "manajemen strategi dapat mengurangi ketidakpastian dan kekomplekan dalam menyusun perencanaan sebagai fungsi manajemen, dan dalam proses pelaksanaan pekerjaan dengan menggunakan semua sumber daya yang secara nyata dimiliki melalui proses yang terintegrasi dengan fungsi manajemen yang lainnya dan dapat dinilai hasilnya berdasarkan tujuan organisasi." Secara terinci manfaat manajemen strategi bagi organisasi non profit (pendidikan) adalah : 
1) Organisasi pendidikan (sekolah) sebagai organisasi kerja menjadi dinamis, karena RENSTRA dan RENOP harus terus menerus disesuaikan dengan kondisi realistik organisasi (analisis internal) dan kondisi lingkungan (analisis eksternal) yang selalu berubah terutama karena pengaruh globalisasi. Dengan kata lain Manajemen Strategi sebagai pengelolaan dan pengendalian yang bekerja secara realistik dalam dinamikanya, akan selalu terarah pada Tujuan Strategi dan Misi yang realistik pula.

2) Implementasi Manajemen strategi melalui realiasi RENSTRA dan RENOP berfungsi sebagai pengendali dalam mempergunakan semua sumber daya yang dimiliki secara terintegrasi dalam pelaksanaan fungsi - fungsi manajemen, agar berlangsung sebagai proses yang efektif dan efisien. Dengan demikian berarti Manajemen Strategi mampu menunjang fungsi kontrol, sehingga seluruh proses pencapaian Tujuan Strategi dan perwujudan Visi berlangsung secara terkendali.

3) Manajemen Strategi diimplementasikan dengan memilih dan menetapkan strategi sebagai pendekatan yang logis, rasional dan sistematik, yang menjadi acuan untuk mempermudah perumusan dan pelaksanaan program kerja. Strategi yang dipilihdan disepakati dapat memperkecil dan bahkan meniadakan perbedaan dan pertentangan pendapat dalam mewujudkan keunggulan yang terarah pada pencapaian tujuan strategi.

4) Manajemen Strategi dapat berfungsi sebagai sarana dalam mengkomunikasikan gagasan, kreativitas, prakarsa, inovasi dan informasi baru serta cara merespon perubahan dan perkembangan lingkungan operasional, nasional dan global, pada semua pihak sesuai dengan wewenang dan tanggung jawabnya. Dengan demikian akan memudahkan dalam menyepakati perubahan atau pengembangan strategi yang akan dilaksanakan, sesuai dengan atau tanpa merubah keunggulan yang akan diwujudkan oleh organisasi.

5) Manajemen Strategi sebagai paradigma baru di lingkungan organisasi pendidikan, dapat mendorong perilaku proaktif semua pihak untuk ikut serta sesuai posisi, wewenang dan tanggungjawab masing - masing. Dengan demikian setiap unit dan atau satuan kerja akan berusaha mewujudkan keunggulan di bidangnya untuk memperkuat keunggulan organisasi. 
6) Manajemen Strategi di dalam organisasi pendidikan menuntut semua yang terkait untuk ikut berpartisipasi, yang berdampak pada meningkatnya perasaan ikut memiliki (sense of belonging), perasaan ikut bertanggungjawab (sense of responsibility), dan perasaan ikut berpartisipasi (sense of participation). Dengan

kata lain manajemen strategi berfungsi pula menyatukan sikap bahwa keberhasilan bukan sekedar untuk menajemen puncak, tetapi merupakan keberhasilan bersama atau untuk keseluruhan organisasi dan bahkan untuk masyarakat yang dilayani.

Berdasarkan uraian tentang keunggulan dan manfaat manajemen strategi di atas perlu dipahami bahwa pengimplementasiannya di lingkungan organisasi pendidikan bukanlah jaminan kesuksesan. Keberhasilan tergantung pada SDM atau pelaksananya bukan pada Manajemen Strategi sebagai sarana. SDM sebagai

Pelaksana harus terdiri dari personil yang profesional, memiliki wawasan yang luas dan yang terpenting adalah memiliki komitmen yang tinggi terhadap moral dan/atau etika untuk tidak menggunakan manajemen strategi demi kepentingan diri sendiri atau kelompok. 


\section{BAB IV}

\section{KESIMPULAN}

Dari uraian di atas penulis dapat menarik kesimpulan tentang keunggulan implementasi dan manfaat manajemen strategi dalam organisasi pendidikan, yaitu :

1. Keunggulan Implementasi Manajemen Strategi Dengan menerapkan Manajemen Strategi, maka organisasi pendidikan (sekolah) akan memiliki keunggulan, antara lain : profitabilitas, produktifitasi tinggi, memiliki posisi kompetitif, keunggulan teknologi, keunggulan Sumber Daya Manusia, Iklim kerja yang kondusif, etika dan tanggung jawab sosial yang berkembang.

\section{Manfaat Manajemen Strategi}

Manfaat yang diperoleh dari implementasi manajemen strategi adalah :

- Organisasi menjadi dinamis,

- Fungsi kontrol berjalan dengan efektif dan efisien

- Meniadakan perbedaan dan pertentangan pendapat dalam mewujudkan keunggulan

- Memudahkan dalam menyepakati perubahan atau pengembangan strategi yang akan dilaksanakan

- Mendorong perilaku proaktif bagi semua pihak untuk ikut serta mewujudkan keunggulan

- Meningkatkan perasaan ikut memiliki, berpartisipasi aktif dan tanggung jawab bagi semua komponen organisasi. 


\section{DAFTAR PUSTAKA}

https://naditjahyes.files.wordpress.com/2011/07/makalah-manajemen-strategi.doc

https://www.pelajaran.co.id/2017/03/pengertian-keputusan-dan-pengambilan-

keputusan-menurut-para-ahli.html

https://catatan.nahrowi.com/2018/10/01/17-definisi-manajemen-strategi-menurut-para$\underline{\text { ahli/ }}$

https://www.kajianpustaka.com/2016/11/pengertian-tujuan-dan-proses-manajemen$\underline{\text { strategi.html }}$

https://psychosystem.wordpress.com/2011/02/09/pengambilan-keputusan/ 